\title{
Pacific (2019)
}

\author{
W.John Hopkins*
}

2019 was an eventful year in the South Pacific with developments at both the regional and national levels in the field of disaster law. In addition, the region witnessed several diverse disaster events which posed significant challenges for the legal systems concerned and exposed a number of systemic weaknesses, particularly in the relationship between national and international disaster frameworks.

\section{The Pacific Islands Forum: Actioning the Boe Declaration}

The Pacific Islands Forum (PIF), the South Pacific's regional entity, ${ }^{1}$ enjoyed another significant year with further momentum in the development of regional approaches to disaster law and governance in the Pacific basin. This must be understood in the wider context of a push to develop stronger regional architecture under the 'Blue Pacific' framework. A key element of this has seen Pacific Island leaders commit to deeper levels of regional co-operation through an expanded conception of security under the 2018 Boe Declaration. ${ }^{2}$ As a result of this declaration, PIF Member States explicitly recognised the importance of 'human security, including humanitarian assistance' as part of future co-operation amongst PIF Member States. In 2019 these high-level political statements were given practical form through the Boe Declaration Action Plan. ${ }^{3}$ This document provides a framework for the implementation of the declaration across a wide range of areas, including disaster response and mitigation.

* Professor of Law, Law School, University of Canterbury. The author wishes to acknowledge the assistance of Gabrielle Emery (IFRC Regional Disaster Law Coordinator, Kuala Lumpur) and Finau Heuifanga Leveni in the preparation of this report. Any errors or omissions are those of the author.

1 The Pacific Islands Forum is not technically an International Organisation.

2 Boe Declaration on Regional Security (2018). See W. John Hopkins, 'Pacific (2018)', (2019) 1 YIDL, 268.

3 Pacific Islands Forum Secretariat, Action Plan to Implement the Boe Declaration on Regional Security (Boe Declaration Action Plan - 2018), <https://www.forumsec.org/wp-content/ uploads/2019/10/BOE-document-Action-Plan.pdf > last accessed (as any subsequent URL) on 18 May 2020. 
Of particular relevance to International Disaster Law is Strategic Focus Area 2 'Human Security and Humanitarian Assistance'. Most of this focus area is relatively anodyne and tends to focus on existing achievements and frameworks (including the Framework for Resilient Development in the Pacific - FRDP; the Pacific Islands Emergency Management Alliance; and the Pacific Meteorological Council) although providing additional targets and support for these entities and agreements. ${ }^{4}$ However, the plan also contains a commitment for all PIF states to expand and modernise their existing disaster management frameworks. ${ }^{5}$ This is particularly important as many PIF states operate under ageing and outdated legal frameworks. Although these commitments are important, particularly in a Pacific context, there is one additional element of the action plan that is potentially revolutionary. This is the commitment to develop 'a regional coordination mechanism for disaster preparedness and response'. ${ }^{6}$ Although the idea of a regional disaster response mechanism has been regularly mooted, primarily by NGOS and academics, this is not something that has seen much discussion amongst policy makers until now. ${ }^{7}$

Perhaps influenced by the ASEAN model (which NGOs have promoted in the region), the proposed Pacific disaster response agency will specifically include pre-positioning of approved goods and the pooling of resources. Specific targets that have been identified by the plan include the development of Standard Operating Procedures for regional response and a clear indication of PIF resources available for regional and global deployment. Interestingly, the agency will also have the authority to intervene in wider issues requiring "humanitarian assistance" beyond that of disasters, perhaps reflecting the experiences of the ASEAN Coordinating Centre for Humanitarian Assistance on Disaster Management (AHA Centre), which has operated (often controversially) in areas not originally seen as its remit in recent years. ${ }^{8}$

The Action Plan's Strategic Focus Area 6 also provides for a proposed policy co-ordination mechanism, although this addresses the 'expanded concept of security' envisaged in the Boe declaration as a whole rather than disaster

4 Boe Declaration Action Plan, Strategic Focus Area 2 (iv).

5 Ibid., (vi).

6 Ibid., (viii).

7 See W. John Hopkins, 'Soft Obligations and Hard Realities: Regional Disaster Risk in Europe and Asia' in Katja L. H. Samuel, Marie Aronsson-Storrier, Kirsten Nakjavani Bookmiller (eds), The Cambridge Handbook of Disaster Risk Reduction and International Law (CUP 2019) 219.

8 In particular, in providing aid during the Rohinga (Myanmar) and Marawi (Philipines) crises. 
risk management specifically. ${ }^{9}$ The details of the mechanism are not provided in the Action Plan, but it is intended to have the power to make 'decisions' which suggests a degree of supra-nationalism that is rare in a Pacific context. ${ }^{10}$ It should also be noted that the language used to describe this mechanism seems more focussed on traditional security (perhaps reflecting the priorities of the two metropolitan states in the region). ${ }^{11}$ Nevertheless, this body will still provide the potential for increased political co-ordination in the disaster field where little has existed in the past.

In common with the rest of the action plan, these elements will be subject to an annually reviewed delivery document which will further define specific activities to realise the goals of the action plan and thus the declaration itself. It will be interesting to see how the action plan's ambitious aims, particularly in regard to the creation of a regional disaster response framework, are translated into practice. A series of meetings are scheduled for early 2020 to expand upon the broad principles established in the Action Plan.

These developments are of interest even beyond the disaster law sphere as they hold out the tantalising prospect of a level of regional co-operation that is uncommon in the Pacific basin. Perhaps disaster response could thus provide the 'limited and decisive point'12 to encourage deeper Pacific Island co-operation that has until now eluded the PIF states?

Alongside the nation-state focus of the Boe Declaration, 2019 also saw advances in NGO and Pacific Island state disaster risk resilience co-ordination under the new Pacific Resilience Partnership (PRP). This partnership was established in 2017 to support the effective implementation of the FRDP and in effect replaced the NGO-led Pacific Humanitarian Team. 2019 saw further development of the PRP with the establishment of five Technical Working Groups. Two of these (Risk Governance and Disaster Risk Financing) are of particular relevance to the development of international disaster law in the Pacific Region. ${ }^{13}$ Although the Disaster Risk Financing working group is in its infancy, working

\footnotetext{
9 Boe Declaration Action Plan, Strategic Focus Area 6C.

$10 \quad$ Ibid., (vi).

11 Australia and New Zealand.

12 Jean Monnet, memorandum to Robert Schuman and George Bidet, 4th May 1950.

13 See <http://www.resilientpacific.org/technical-working-groups/>.
} 
group 5 (dealing with risk governance) has made significant early progress. This working group, jointly chaired by the Solomon Islands, the IFRC and the Pacific Islands Forum Secretariat, comprises National Disaster Management Organisation (NDMO) representatives from a number of PIF states alongside representatives from Attorney General's Offices. ${ }^{14}$ This novel combination provides the potential for significant and practical advances in the implementation of both the FRDP and the Boe Declaration in the legal sphere.

One of the early areas of focus for the risk governance working group will be to map existing legislative frameworks and disaster law (including climate change). This will build upon current IFRC-managed work to map and make such information available. ${ }^{15}$ From this baseline, the working group will be in a position to support co-operation to allow practical delivery of the FRDP's aims and the regional mechanism(s) envisaged by the Boe Declaration Action Plan. These are significant milestones in a region where co-operation is practically difficult and pan-regional links are often weak.

\section{3}

\section{National DR R Governance in the Pacific: Modernisation and Enhanced Coherence}

The region continues to experience significant changes at the national level, with a number of states revising and modernising their national disaster law frameworks. Many of these changes have regional and international relevance. In 2019, two states stood out in this regard, for very different reasons. In Vanuatu, after many years of delay, the Parliament finally passed the new Disaster Risk Management Act (2019) in December. This introduces an entirely new framework for DRM in Vanuatu and repeals the 2000 National Disaster Act. The Act is the culmination of a long period of review and reflection following the aftermath of Cyclone Pam in 2015. The resultant legislation was significantly influenced by the IFRC, who were involved in its early drafting process. This has resulted in a form of legislation which, although tailored to the realities of Vanuatu, has a number of similarities with other recent Pacific DRM legislation..$^{16}$ In particular, the consolidation of requests for international assistance under a single framework, the barring of unsolicited aid and the

\footnotetext{
14 The current membership comprises representatives from Fiji, Kiribati, Solomon Islands, Palau, Republic of Marshall Islands (RMI), Samoa, Tuvalu, and Tonga.

15 This work has not yet been made publicly available.

16 See for example, Nauru Disaster Risk Management Act 2016.
} 
establishment of the NDMO as the focal point for international assistance reflect an emerging Pacific standard in national DRM frameworks.

In New Zealand, the creation of the new National Emergency Management Agency (NEMA) reflects lessons learnt from the Canterbury and Kaikoura earthquake sequences. In particular, these exposed weaknesses within the Ministry of Civil Defence and Emergency Management and confusion about its role. The decision was taken to create a new agency with an expanded and clarified remit. Within this model, Civil Defence remains statutorily independent and many of the formal powers provided within the Civil Defence and Emergency Management Act remain within the Director of Civil Defence (who is currently also the Deputy Director of NEMA).

The development of NEMA has also occurred in parallel with the new National Disaster Resilience Strategy 2019 which provides for a broader allof-government resilience-focussed approach to policy to be overseen by the new agency. However, interestingly, the changes still lack some of the all-ofgovernment planning structures that exist in many Pacific Island states which, of course, have been influenced by international disaster law norms. Notably, the new NEMA model is explicitly focussed on operational matters rather than strategy with a number of issues (transport resilience, for example) explicitly transferred to the Transport Agency. While this is understandable, the lack of an agency or mechanism to explicitly drive overall disaster risk prevention and mitigation is a potential weakness. Instead, New Zealand's structure still seems to have a focus on a narrow definition of security with significant roles for the Intelligence Services in the National Security System. ${ }^{17}$ This seems to reflect the political focus placed upon these matters rather than a reflection of the real risks that South Pacific nations face.

Beyond these major legislative and constitutional changes, a number of other Pacific states have experienced significant DRR policy change in the past year. This has seen the introduction of a new National Disaster Risk Management Plan for Fiji, again involving external advice from the IF RC. As yet, this plan sits within the context of an outdated disaster law framework, ${ }^{18}$ although a modernised draftDisasterManagement Actis currentlyunder discussion. Anewdraft DRM Act is also under discussion in Papua New Guinea, while there are moves

\footnotetext{
17 See 'National Security System Handbook', Department of Prime and Cabinet (2016) <https://dpmc.govt.nz/sites/default/files/2017-03/dpmc-nss-handbook-aug-2016.pdf>.

18 The current disaster framework in Fiji is underpinned by the Natural Disaster Management Act 1998 .
} 
in Palau to finally create a single disaster management act to underpin the current DRM framework. ${ }^{19}$

Overall, the acceptance of the need for modern DRM legislative frameworks which reflect both the needs of individual states (and communities) and the requirements of international actors is gathering pace across Pacific Island states. The compatibility of many of these legislative frameworks bodes well for the creation of the regional response mechanism discussed above.

\section{$4 \quad$ The Pacific Measles Epidemics: A Governance Disaster?}

Despite the attempts to improve and modernise the legal frameworks disaster risk management discussed above, 2019 also provided a stark reminder of the consequences of poor governance in such situations. Measles made an unwelcome return to the Pacific, with New Zealand being gripped by an epidemic in the latter months of the year (and continuing into 2020). This led to over 2.000 confirmed cases (mostly concentrated in the Auckland region). New Zealand's response was relatively effective in containing the virus domestically (although it did raise questions around the effectiveness of its vaccination policy and the problems of anti-vaccination misinformation being spread in the community). However, New Zealand's attempts to limit its spread internationally proved inadequate and it is almost certain that the New Zealand outbreak led directly to the Samoan epidemic which began in September 2019. ${ }^{20}$

The Samoan epidemic saw around $3 \%$ of the population being infected (over 5.500 people) and the deaths of 87 children. The Samoan state struggled to cope with the outbreak and early governance errors around vaccination policy and the use of emergency powers in particular appear to have made the situation worse. The devastating nature of the outbreak had its roots in the tragic death of two children after a vaccination (caused by poor practice on the part of nurses administering the vaccine). ${ }^{21}$ This led to the Samoan Government suspending its vaccination programme for 10 months. This was coupled with

19 The Palau DRM system is currently based upon an executive decree (Palau Executive Order No 397).

20 See <https://www.rnz.co.nz/news/national/405411/mfat-confirms-new-zealand-as-likely -source-of-samoa-s-measles-epidemic $>$.

21 Expired muscle relaxant was used to dilute the vaccine rather than water. See 'Baby deaths caused by incorrect vaccination procedure - Samoa health ministry confirms', RNZ (6 June 2019) <https://www.rnz.co.nz/international/pacific-news/39134o/baby-deaths -caused-by-incorrect-vaccination-procedure-samoa-health-ministry-confirms >. 
significant activities by external "anti-vaccination" groups within Samoa, with the result that vaccination rates dropped to around $30 \%$.

This population was thus already vulnerable to a measles epidemic when the New Zealand outbreak spread to the island in September 2019. However, the situation was made worse by the failure to declare an early state of emergency and an apparent unawareness of the need to do so to allow external aid to be effectively delivered. ${ }^{22}$ These early failures led to a significant lack of resources to deal with the immediate vaccination programme that was launched in December 2019. Crucially, poor isolation between those attending hospital with the virus and families attending to get vaccinations for their children led, almost certainly, to further transmission of the disease. Despite criticism and concerns that the DRM system did not perform well, the Samoan Government has, as yet, refused to conduct a public inquiry into the outbreak and the government's response to it. In a country where the same party has been in government since 1982 and 47 out of the 50 Members of Parliament remain members of the governing party, lack of scrutiny of government decisions is not uncommon. However, such a lack of reflection is concerning and leads to the fear that effective lessons may not be learned. ${ }^{23}$ It is a further reminder of the intimate connection between effective disaster response, good governance and the Rule of Law.

\section{5} 2019: A Year of Progress and Pathos

2019 proved to be a year of contrasts for the Pacific in the field of disaster law and governance. Alongside the appearance of early positive signs that the Boe Declaration may lead to significant moves towards a regional (and indigenous) response mechanism and further improvements in domestic DRR legal frameworks, the region experienced significant disasters which appear to have been worsened by poor disaster law frameworks (or poor application of them).

In addition, the moves towards modernisation of both national and regional disaster law often remain tied to wider concepts of "national security". While this has been a useful vehicle in a regional context and is at least one of the

\footnotetext{
22 "These babies should not have died": How the measles outbreak took hold in Samoa', The Guardian (17 December 2019) <https:/www.theguardian.com/world/2019/dec/18/ these-babies-should-not-have-died-how-the-measles-outbreak-took-hold-in-samoa .

23 'Top doctor joins call for measles crisis review', Samoa Observer (21 February 2019) $<$ https://www.samoaobserver.ws/category/samoa/58465>.
} 
reasons for the early positive signs around the Boe declaration's implementation, it remains a risk that such an association could lead to the development of inappropriate structures or an inappropriate role for military or security agencies. These agencies have a very different culture and management ethos to civil protection/defence agencies, and the NGOs which often support them, in the Pacific. Only time will tell if the expanded approach to security proves a poison chalice to the development of disaster law in the Pacific region and its constituent states. 